\title{
Removal of nutrient and heavy metal loads from sewage effluent using vetiver grass, Chrysopogon zizanioides (L.) Roberty
}

\author{
T Mudhiriza', F Mapanda'*, BM Mvumi' and M Wuta',2 \\ 'Department of Soil Science and Agricultural Engineering, University of Zimbabwe, P.O. Box MP167, Mt. Pleasant, Harare, Zimbabwe \\ ${ }^{2}$ Marondera College of Agricultural Science and Technology, University of Zimbabwe, P. O. Box 35, Marondera, Zimbabwe
}

\begin{abstract}
Urban cities in many developing nations face the challenge of relieving the pressure exerted on overloaded sewage treatment works. Apart from limited financial capacity, complementary treatment methods like phyto-extraction of pollutants from the effluent have not been fully exploited, particularly in southern Africa. A study was conducted in Harare, Zimbabwe, to assess the potential of vetiver grass, Chrysopogon zizanioides, in removing N, P, Zn, Mn and Ni loads in sewage effluent from primary clarification, under hydroponic conditions. Vetiver grass was grown from tillers on floating trays suspended in effluent, and the total concentrations of selected parameters were monitored in both effluent and vetiver grass at $0,7,14$ and 21 days of retention in effluent. Higher pollutant reduction (62-100\%) in effluent, with respect to all parameters, under vetiver grass compared to no vetiver treatment (9-27\%), was recorded by Day 21. Effluent $\mathrm{pH}$ remained stable at 7.44-7.64. Smaller changes were found for $\mathrm{N}\left(9.8\right.$ from $\left.27.5 \mathrm{mg} \cdot \ell^{-1}\right)$ and $\mathrm{P}\left(2.0\right.$ from $\left.5.3 \mathrm{mg} \cdot \ell^{-1}\right)$ than for the heavy metals. Vetiver grass dry biomass accumulated at 3.8-4.7 g.tiller ${ }^{-1}$. week $^{-1}$, while heavy metal extraction (up to $6.2 \mathrm{mg} \mathrm{Zn,} 3.3 \mathrm{mg} \mathrm{Mn}$ and $0.06 \mathrm{mg}$ $\mathrm{Ni}$ tiller $\left.{ }^{-1}\right)$ by root uptake increased with time at an exponential rate $\left(R^{2}, 0.73-0.83\right)$. The study established that, while root uptake was a significant feature of the clean-up process, the corresponding high reduction of heavy metals in effluent suggests multiple removal mechanisms, including bio-sorption by microorganisms producing an immobilised microbial biomass on the container wall. A deliberate lowering of effluent $\mathrm{pH}$ may increase root uptake thereby possibly reducing the clean-up time and improving effluent quality. There is potential for application of this technology in cities struggling with the cost of conventional sewage treatment.
\end{abstract}

Keywords: bio-accumulation, bio-sorption, heavy metals, hydroponic, nitrogen, phosphorus

\section{INTRODUCTION}

The primary objective of wastewater treatment is to allow human and industrial effluents to be disposed of without danger to human health or unacceptable damage to the natural environment (Pescod, 1992). Apart from safe disposal, treatment of wastewater reduces the cost of water purification, especially in cases where the catchment basins receiving treated effluent are also the main sources of domestic water. This is largely the case of Lake Chivero in Harare, Lake Mutirikwi in Masvingo, and many other catchments within which the major cities of Zimbabwe are located. Many studies have reported considerable damage to the natural environment and potential health risks that were attributed to inadequate treatment and poor disposal of sewage in Zimbabwe (Nyamangara and Mzezewa, 1999; Madyiwa et al., 2002; Mapanda et al., 2005; 2007; Ndebele and Mzime, 2012). On the same note, the attempts to relieve pressure on the overloaded sewage treatment works have been hindered by lack of financial capacity, more than lack of technical capacity (Thebe and Mangore, 2012). However, it is apparent that limited research on cheaper complementary sewage treatment methods could also have diminished the hope of finding sustainable solutions to the wastewater treatment problem.

Most conventional sewage treatment methods incorporate mechanical and chemical processes that are labour-intensive, require large amounts of energy resources, and are costly

\footnotetext{
* To whom all correspondence should be addressed.

ฮ +263-4-303211 ex 15538; e-mail: faraimaps@yahoo.com; faraimaps@agric.uz.ac.zw
}

Received 17 January 2014; accepted in revised form 28 May 2015
(Prasad, 2011). The restructuring of existing sewage and water plants and their pumping stations, which came into effect in June 2013, is projected to cost about ZAR1 440 million (ZAR10 $\approx$ USD1 as at June 2013) for Harare alone (CMEC, 2013). However, there are a number of sewage treatment methods that can perform a complementary function for a centralised sewage treatment system. Gutterer et al. (2009) described some decentralised wastewater treatment systems designed by planners and engineers in developing countries to reduce system overloading and overall generation of wastewater. One of the key components of these systems is the use of plants to remove nutrient loads from wastewater that has gone through the initial sedimentation process.

The extraction of nutrients from sewage using a freefloating plant, water hyacinth, Eichhornia crassipes, may have been one of the earliest attempts to decentralise wastewater treatment in Zimbabwe. It, however, became problematic when the noxious weed colonised large areas of waterways, mainly because E. crassipes had no natural enemies in Zimbabwe, and caused anoxic conditions upon its decomposition (Mahamadi, 2011). Many studies worldwide have given a non-invasive plant, vetiver grass, Chrysopogon zizanioides (L.) Roberty, as an answer to low-cost complementary technology in sewage treatment systems (Boonsong and Chansiri, 2008; Gerrard, 2008; Roongtanakiat, 2009; Gupta et al., 2012; Paz-Alberto and Sigua, 2013). In their support, researchers argue that vetiver grass has a high absorption rate for nutrients and heavy metals in wastewater, and a high adaptive capacity under different climatic and growth media conditions. However, the plant is not free-floating, like most waterweeds. Truong and Baker (1998) reported on a water purification study in China, which showed that vetiver grass can reduce soluble P by up to $99 \%$ after 3 weeks, 
and soluble $\mathrm{N}$ by up to $74 \%$ after 5 weeks, and had potential to remove up to $102 \mathrm{t} \mathrm{N}$ and $54 \mathrm{t} \mathrm{P}$ per hectare of vetiver per year. Such properties could make this plant suitable as a cheaper and more effective complementary treatment option for sewage effluent in Harare.

The objective of the current study was to assess the potential of vetiver grass in removing nutrient and heavy metal loads from wastewater composed of both domestic and industrial sewage effluent in Harare, Zimbabwe. Many researchers have used vetiver grass for the removal of water contaminants but the responses differed with climatic conditions as well as the concentration of the contaminants (Gupta et al., 2012). It was therefore hypothesised that vetiver grass grown on floating platforms in sewage effluent without soil media can accumulate significant biomass while effecting significant extraction of nutrients and heavy metals through its root system under the local conditions in Harare.

\section{MATERIALS AND METHODS}

\section{Study sites, floating platform installation and treatments}

The study was conducted between February and May 2013 in a glasshouse at the University of Zimbabwe in Harare, using untreated sewage effluent from the Firle Sewage Treatment Works (FST-Works) and propagated vetiver grass cuttings from Environment Africa in Harare. A glasshouse was used to avoid effluent dilution by incoming rainfall but allowed free movement of ambient air to reduce the differences in temperature and humidity between the inside and outside. The FST-Works extends from $30^{\circ} 55.97^{\prime} \mathrm{E}$ to $30^{\circ} 56.33^{\prime} \mathrm{E}$, and lies between $17^{\circ}$ $55.78^{\prime} \mathrm{S}$ and $17^{\circ} 56.20^{\prime} \mathrm{S}$ in south-west Harare. It processes more than $180000 \mathrm{~m}^{3} \cdot$ day $^{-1}$ of mixed domestic-and-industrial sewage, while its design capacity is about $144000 \mathrm{~m}^{3}$. day ${ }^{-1}$ (Nhapi, 2009). Thus the system has been overloaded. Currently, the treatment works uses the conventional biological trickling filtration system and the activated sludge biological nutrient removal system for sewage treatment.

Hydroponic stations were constructed from floating rafts and plastic containers using a procedure adapted from Truong and Hart (2001), Boonsong and Chansiri (2008), and Gerrard (2008). A total of 16 floating raft trays were designed from kaylite material, each measuring $0.5 \mathrm{~m}$ in diameter and having 6 cells. The rafts were overlaid on 16 plastic containers, each with a capacity of $9 \ell$ and a height of $0.2 \mathrm{~m}$. The experiment was a 2 (with and without vetiver grass) $\mathrm{x} 4$ (effluent retention time: 0 , 7,14 and 21 days) factorial, laid out in a completely randomised design with 4 replicates.

Untreated effluent from FST-Works was collected into a 200- $\ell$ plastic drum. The effluent was collected soon after the primary sedimentation and before biological nutrient removal. The effluent was added into the 16 containers to a volume of $9 \ell$ each. Before adding the effluent, a total of 64 vetiver grass tillers were collected from a nursery and their roots were dipped in distilled water for 21 days in the glasshouse. This was meant to make the plants adapt from being xerophytes to hydrophytes, as recommended by Maffei (2002) and Truong (2007). After 21 days, the aerial part of each tiller was cut at $4 \mathrm{~cm}$ from the crown area, taking care not to damage the roots. In all treatments that had vetiver grass the plants were fixed in positions by their crowns on the floating raft trays, with one tiller per cell. The trays were then overlaid on the containers to float, with the roots submerged in effluent and sticking out from the tray bottom. This set up was maintained for up to 21 days.

\section{Sampling and sample preparation}

Two replicate samples of untreated effluent, each measuring $0.5 \ell$, were collected for initial characterisation from the $200-\ell$ drum with bulk effluent from FST-Works. The samples were collected after mixing using a plastic plunger. Effluent from containers under the floating platforms with and without vetiver grass was also sampled at $0,7,14$ and 21 days of retention. To facilitate sample collection, the float trays were temporarily removed at each sampling occasion and $0.2 \ell$ of effluent was extracted after thorough mixing of the effluent using a plastic plunger. The effluent samples were immediately taken to the laboratory for analysis.

Vetiver grass was sampled just before fixing on the floating trays, and at 7,14 and 21 days of retention on the floating trays. At each sampling 2 plants from each tray were randomly selected and pulled out as whole plants including their roots. The samples were first air-dried in an open shed for 7 days to remove much of the water in the tissues, then oven-dried at $70^{\circ} \mathrm{C}$ for $24 \mathrm{~h}$ (Campbell and Plank, 1998) and weighed. After oven drying the samples were ground and passed through a 2-mm mesh sieve before their analysis in the laboratory.

\section{Analysis of samples}

Effluent from FST-Works was analysed for $\mathrm{pH}$, total dissolved solids, electrical conductivity and total concentrations of $\mathrm{N}, \mathrm{P}$, $\mathrm{Zn}, \mathrm{Ni}$ and $\mathrm{Mn}$, immediately after collection, and for the same nutrients and heavy metals at $0,7,14$ and 21 days of effluent retention using the methods of water analysis described by Sauter and Stoub (1990) and APHA (1999). All the glassware and crucibles used in the analysis of samples were acid-washed prior to analyses. Effluent $\mathrm{pH}$ was measured using a $\mathrm{pH}$ meter (model: Mettler Toledo EL-20) calibrated using buffer $\mathrm{pH} 4$ and 7. Electrical conductivity was measured using the conductivity meter (model: WTW Inolab Cond Level 1) calibrated using $0.1 \mathrm{M} \mathrm{KCl}$, after the sample was filtered into a beaker. Total dissolved solids were measured gravimetrically by evaporating $0.1 \ell$ of filtered effluent in a previously weighed beaker at $100^{\circ} \mathrm{C}$ to a constant weight. The difference between the initial and final beaker weight represented the total dissolved solids.

Total $\mathrm{N}$ in effluent was measured using the Kjeldhal method in which the sample was digested using concentrated $\mathrm{H}_{2} \mathrm{SO}_{4}$ followed by steam distillation after alkalination with $\mathrm{NaOH}^{2}$ in the presence of Devarda's alloy. The amount of $\mathrm{N}$ in the sample was determined colorimetrically using the UV-Vis Spectrophotometer after nesslerisation. Total $\mathrm{P}$ was determined colorimetrically after the effluent sample was digested using concentrated $\mathrm{H}_{2} \mathrm{SO}_{4}$. Total $\mathrm{Zn}, \mathrm{Ni}$ and $\mathrm{Mn}$ were determined using the atomic absorption sprectrophotometric method (AAS model: Varian AA50), after dissolving suspended metals by digestion using aqua regia (mixture of concentrated $\mathrm{HCl}$ and $\mathrm{HNO}_{3}$ at a ratio of 3:1) with external heating, obtaining a supernatant solution after centrifuging. The detection limits for $\mathrm{Zn}$, $\mathrm{Ni}$ and $\mathrm{Mn}$ were $0.002,0.02$ and $0.005 \mathrm{mg} \cdot \ell^{-1}$, respectively.

Vetiver grass was analysed for dry biomass, and total concentrations of $\mathrm{Zn}, \mathrm{Ni}$ and $\mathrm{Mn}$ at 7, 14 and 21 days of effluent retention. At each respective retention time, dry mass of the vetiver grass was weighed using analytical balance before being ground and passed through a 2-mm sieve. The total concentration of $\mathrm{Zn}, \mathrm{Ni}$ and $\mathrm{Mn}$ in vetiver grass were determined using the atomic absorption sprectrophotometric method after ashing each ground plant sample in a crucible in a muffle furnace (Model: Wildbarfield M1354) at $450^{\circ} \mathrm{C}$ for $24 \mathrm{~h}$. The ash was digested using aqua regia and a supernatant solution was obtained by centrifuging before reading on an AAS. 


\section{Data analysis}

Sample analysis data were subjected to homogeneity of variance and normality tests using the Levene's and Kolmogorov-Smirnov's tests, respectively, at the $5 \%$ level. One-way multivariate analysis of variance was carried out on data from plant analysis to establish any significant treatment effects $(P<0.05)$. However, effluent data did not meet all assumptions of normality and homogeneity of variance, even after transformation; hence the Kruskal-Wallis one-way analysis of variance was used, while a pair-wise separation of significantly different treatment means was done using the Mann-Witney test. Bivariate correlation analysis (two-tailed) was performed using the Spearman's Rank Correlation Coefficient (rs). Genstat 14 Edition (Lawes Agricultural Trust, UK) and SPSS 16.0 (SPSS Inc., USA) statistical packages were used in data analysis.

\section{RESULTS}

\section{Characteristics of sewage effluent}

The selected properties of untreated effluent from FST-Works were in the red (high hazard) category in terms of total N, P, Zn, $\mathrm{Mn}, \mathrm{Ni}$ and total dissolved solids, according to the Effluent and
Solid Waste Disposal Regulations in Zimbabwe (Table 1). The heavy metals deviated from the prescribed limits more than a 100 -fold, followed by P and total dissolved solids ( $>10$-fold), and, lastly, $\mathrm{N}$ which was more than twice the permissible limit.

\section{Removal of pollutants from effluent}

The resultant characteristics of effluent at different retention periods with and without vetiver grass are presented in Table 2 . All parameters responded to both vetiver and time of retention with the exception of $\mathrm{pH}$. No $\mathrm{Zn}$ and $\mathrm{Mn}$ could be detected in the effluent by Day 14 of retention under vetiver grass, while the treatment without vetiver had only lost 9 and $11 \%$ of initial $\mathrm{Zn}$ and $\mathrm{Mn}$, respectively, in the same period of retention. By Day 21 of retention total $\mathrm{Ni}$ in effluent was significantly reduced $(P$ $<0.05$ ), by $77 \%$, under vetiver treatment, although the remaining concentration was still above the permissible limit. Total $\mathrm{P}$ in the effluent under vetiver treatment had decreased $(P<0.05)$ by $62 \%$ at Day 21 of retention, compared with a $22 \%$ decrease under no vetiver grass for the same period.

Vetiver grass was able to reduce the amount of total $\mathrm{N}$ and total dissolved solids in effluent to levels that were acceptable for disposal at Day 21 of retention. This translated to a 64 and

\begin{tabular}{|c|c|c|}
\hline \multicolumn{3}{|c|}{$\begin{array}{l}\text { TABLE } 1 \\
\text { Selected properties of untreated sewage effluent from Firle Sewage Treatment Works in Harare compared to permissible } \\
\text { limits according to the national regulations* }(n=2) .\end{array}$} \\
\hline Parameter & Mean total concentration \pm std. dev. & Permissible limit \\
\hline $\mathrm{pH}$ & $7.6 \pm 0.1$ & $6.0-9.0$ \\
\hline Electrical conductivity $\left(\mathrm{dS} \cdot \mathrm{m}^{-1}\right)$ & $6.6 \pm 4.5$ & 10 \\
\hline Total dissolved solids $\left(\mathrm{g} \cdot \ell^{-1}\right)$ & $7.0 \pm 0.0$ & 0.5 \\
\hline Total nitrogen $\left(\mathrm{mg} \cdot \ell^{-1}\right)$ & $27.5 \pm 0.2$ & 10 \\
\hline Total P $\left(\mathrm{mg} \cdot \ell^{-1}\right)$ & $5.3 \pm 0.3$ & 0.5 \\
\hline Zinc $\left(\mathrm{mg} \cdot \ell^{-1}\right)$ & $63.7 \pm 0.2$ & 0.5 \\
\hline Nickel $\left(\mathrm{mg} \cdot \ell^{-1}\right)$ & $51.4 \pm 0.1$ & 0.3 \\
\hline Manganese $\left(\mathrm{mg} \cdot \ell^{-1}\right)$ & $31.0 \pm 0.3$ & 0.1 \\
\hline
\end{tabular}

${ }^{*}$ Environmental Management (Effluent and Solid Waste Disposal) Regulations (2007)

TABLE 2

Mean effluent pH, electrical conductivity (EC), total dissolved solids (TDS) and total concentrations of selected nutrients and heavy metals under different treatments $(n=4)$.

\begin{tabular}{|c|c|c|c|c|c|c|c|c|}
\hline Treatment & pH & EC & TDS & $\mathbf{N}$ & $\mathbf{P}$ & Zn & $\mathrm{Ni}$ & Mn \\
\hline & & $\mathrm{dS} \cdot \mathrm{m}^{-1}$ & \multicolumn{6}{|c|}{$\mathrm{mg} \cdot \mathrm{l}^{-1}$} \\
\hline - Vetiver, 00 day & 7.62 & $6.6^{\mathrm{f}}$ & $7025^{\mathrm{e}}$ & $27.5^{\mathrm{g}}$ & $5.3^{\mathrm{d}}$ & $63.7^{\mathrm{d}}$ & $51.4^{\mathrm{e}}$ & $31.5^{\mathrm{e}}$ \\
\hline 07 day & 7.59 & $6.5^{\mathrm{f}}$ & $6695^{\mathrm{e}}$ & $25.6^{\mathrm{f}}$ & $4.6^{\mathrm{c}}$ & $59.3^{c}$ & $47.6^{\mathrm{d}}$ & $28.6^{\mathrm{d}}$ \\
\hline 14 day & 7.60 & $6.2^{\mathrm{e}}$ & $5603^{d}$ & $24.3^{\mathrm{e}}$ & $4.1^{\mathrm{b}}$ & $58.1^{\mathrm{c}}$ & $46.1^{\mathrm{c}}$ & $27.8^{\mathrm{d}}$ \\
\hline 21 day & 7.61 & $6.0^{\mathrm{d}}$ & $5138^{c}$ & $23.2^{\mathrm{d}}$ & $4.1^{\mathrm{b}}$ & $58.2^{\mathrm{c}}$ & $43.4^{\mathrm{b}}$ & $26.0^{c}$ \\
\hline + Vetiver, 00 day & 7.62 & $6.6^{\mathrm{f}}$ & $7025^{\mathrm{e}}$ & $27.5^{\mathrm{g}}$ & $5.3^{\mathrm{d}}$ & $63.7^{\mathrm{d}}$ & $51.4^{\mathrm{e}}$ & $31.5^{\mathrm{e}}$ \\
\hline 07 day & 7.64 & $5.1^{\mathrm{c}}$ & $1745^{\mathrm{b}}$ & $21.8^{\mathrm{c}}$ & $4.0^{\mathrm{b}}$ & $21.3^{\mathrm{b}}$ & $14.8^{\mathrm{a}}$ & $16.3^{\mathrm{b}}$ \\
\hline 14 day & 7.53 & $4.7^{\mathrm{b}}$ & $473^{\mathrm{a}}$ & $16.8^{\mathrm{b}}$ & $2.8^{\mathrm{a}}$ & $\mathrm{n} / \mathrm{d}^{\mathrm{a}}$ & $13.0^{\mathrm{a}}$ & $\mathrm{n} / \mathrm{d}^{\mathrm{a}}$ \\
\hline 21 day & 7.44 & $3.9^{\mathrm{a}}$ & $367^{\mathrm{a}}$ & $9.8^{\mathrm{a}}$ & $2.0^{\mathrm{a}}$ & $\mathrm{n} / \mathrm{d}^{\mathrm{a}}$ & $12.0^{\mathrm{a}}$ & $\mathrm{n} / \mathrm{d}^{\mathrm{a}}$ \\
\hline
\end{tabular}

\begin{tabular}{|l|c|c|c|c|c|c|c|c|}
\hline Significance & $\mathrm{n} / \mathrm{s}$ & $*$ & $*$ & $*$ & $*$ & $*$ & $*$ \\
\hline CV\% & 1.1 & 1.7 & 11.4 & 6.1 & 11.8 & 2.4 & 6.6 & 8.8 \\
\hline SED & 0.06 & 0.1 & 348 & 0.9 & 0.3 & 0.7 & 1.6 & 1.3 \\
\hline Permissible limit & $6-9$ & 10 & 500 & 10 & 0.5 & 0.5 & 0.3 \\
\hline
\end{tabular}

${ }^{*}$ Significant at 0.05 probability level; $n / d=$ not detected; $n / s=$ not significant; different letters within a column denote significant differences.

Detection limits $\left(m g \cdot \ell^{-1}\right): Z n=0.002, N i=0.02$ and $M n=0.005$ 
$95 \%$ reduction in total $\mathrm{N}$ and total dissolved solids, respectively, at 21 days of retention. However, at this time the treatment without vetiver had only 16 and $27 \%$ reduction in the levels of these respective parameters.

Results showed significant negative correlation $(P<0.01)$ between retention time and the amounts of N, P, Zn, Mn and electrical conductivity (rs range: -0.93 to -0.97 ), total dissolved solids (rs, -0.77), $\mathrm{Ni}$ (rs, -0.69) and $\mathrm{pH}$ (rs, -0.61) in the effluent under vetiver treatments. In the treatments with no vetiver the correlation was also significant for all parameters $(P<0.01$, rs range: -0.78 to -0.97$)$, except for $\mathrm{pH}(P>0.05)$. The regression analysis revealed distinct relationships between the period of retention under vetiver treatment and the levels of the measured parameters in effluent (Table 3). The relationships were linear for electrical conductivity,
$\mathrm{N}$ and $\mathrm{P}$, and curvilinear (polynomial, second order) with quadratic terms for total dissolved solids, $\mathrm{Zn}, \mathrm{Ni}$ and $\mathrm{Mn}$.

\section{Vetiver grass biomass production and heavy metal uptake}

Survival rate of all vetiver grass tillers on the effluent was $100 \%$. The average dry mass of vetiver grass tillers increased $(P<0.05)$ from $8.9 \mathrm{~g}$ at the start of the experiment to $26.5 \mathrm{~g}$ at Day 21 of effluent retention under vetiver grass (Fig. 1a). A lag phase in biomass accumulation was observed between Day 7 and Day 14, where the mean biomass reached 18.3 and $18.9 \mathrm{~g}$, respectively. Before this phase the biomass had accumulated at an average rate of $4.7 \mathrm{~g} \cdot \mathrm{tiller}^{-1} \cdot \mathrm{week}^{-1}$, and after this phase the biomass accumulation rate was about $3.8 \mathrm{~g} \cdot \mathrm{tiller}^{-1} \cdot \mathrm{week}^{-1}$. The

\begin{tabular}{|c|c|c|c|}
\hline \multicolumn{4}{|c|}{$\begin{array}{l}\text { TABLE } 3 \\
\text { Relationships between the amount of a measured parameter }(Y) \text { in effluent and the retention time }(X, \text { in days) for the } \\
\text { treatments under vetiver grass }\end{array}$} \\
\hline Parameter & Relationship & $r^{2}$ value & $Y$ data range and units \\
\hline $\begin{array}{l}\text { EC } \\
\text { TDS } \\
\mathrm{N} \\
\mathrm{P} \\
\mathrm{Zn} \\
\mathrm{Ni} \\
\mathrm{Mn}\end{array}$ & $\begin{array}{c}Y=6.3-0.12[X] \\
Y=0.027[\mathrm{X}]^{2}-0.86[X]+6.9 \\
Y=27.6-0.85[X] \\
Y=5.3-0.17[X] \\
Y=0.22[X]^{2}-7.57[X]+63.7 \\
Y=0.182[X]^{2}-5.53[X]+49.6 \\
Y=0.078[X]^{2}-3.22[X]+32.4\end{array}$ & $\begin{array}{l}0.94 \\
0.95 \\
0.96 \\
0.91 \\
0.99 \\
0.92 \\
0.95\end{array}$ & $\begin{array}{c}3.8-6.6 \mathrm{dS} \cdot \mathrm{m}^{-1} \\
0.1-7.2 \mathrm{~g} \cdot \ell^{-1} \\
7.0-27.7 \mathrm{mg} \cdot \ell^{-1} \\
1.4-5.6 \mathrm{mg} \cdot \ell^{-1} \\
0-63.9 \mathrm{mg} \cdot \ell^{-1} \\
8.0-51.5 \mathrm{mg} \cdot \ell^{-1} \\
0-31.9 \mathrm{mg} \cdot \ell^{-1}\end{array}$ \\
\hline
\end{tabular}
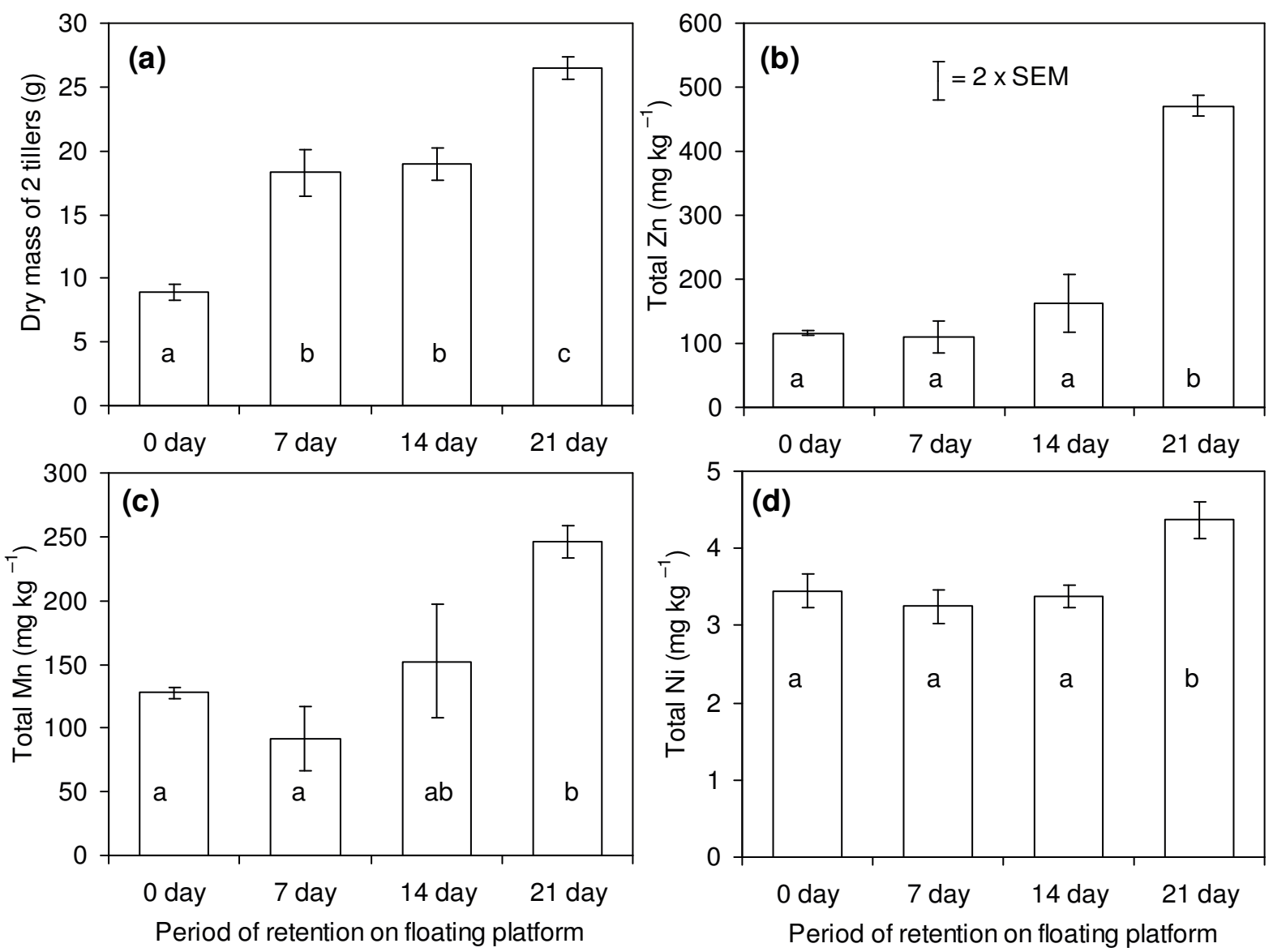

Figure 1

(a) Vetiver grass tiller weight; (b) total concentration of $\mathrm{Zn}$; (c) total concentration of Mn; and (d) total concentration of Ni; under 4 periods of retention on floating platforms above sewage effluent from Firle Sewage Treatment Works. Different letters inside the bars denote significant differences between times at the 0.05 probability level $(n=4)$. 
amounts of $\mathrm{Zn}, \mathrm{Mn}$ and $\mathrm{Ni}$ that accumulated per unit weight of vetiver grass biomass at different effluent retention periods are shown in Figs 1b,c,d. Zinc concentration (means range: $116-471 \mathrm{mg} \cdot \mathrm{kg}^{-1}$ ) showed a significant increase from the initial value only at Day 21 of effluent retention. This trend was also observed with Mn (128-246 mg.kg-1) and $\mathrm{Ni}\left(3.5-4.4 \mathrm{mg} \cdot \mathrm{kg}^{-1}\right.$ ). Nickel had the lowest concentration in vetiver grass, despite the fact that its concentration in effluent was higher than that of Mn (Tables 1 and 2).

In terms of total heavy metal extraction per tiller of vetiver grass (i.e. accumulated biomass multiplied by heavy metal concentration in the biomass), results showed an exponential increase in the bioaccumulation of heavy metals by vetiver grass with time (Fig. 2). The highest extraction was that of $\mathrm{Zn}$ (means: 0.5, 1.0, 1.5 and 6.2 mg.tiller $^{-1}$ at Days 0, 7, 14 and 21, respectively) (Fig. 2a), followed by Mn (means: $0.6,0.8,1.4$ and $3.3 \mathrm{mg}$ tiller $^{-1}$ at the same respective days) (Fig. 2a) and lastly $\mathrm{Ni}$ (means: $0.02,0.03,0.03$ and $0.06 \mathrm{mg} \cdot$ tiller $^{-1}$ also at the same respective days) (Fig. 2b). These averages amounted to net heavy metal removals of $16.4 \mathrm{mg} \mathrm{Zn}, 9.9 \mathrm{mg} \mathrm{Mn}$ and $0.21 \mathrm{mg} \mathrm{Ni}$ from the $9 \ell$ of effluent through summed harvests of Days 7, 14 and 21, against the initial concentrations of 63.7, 31.5 and 51.4 $\mathrm{mg} \cdot \ell^{-1}$ for $\mathrm{Zn}, \mathrm{Mn}$ and $\mathrm{Ni}$ in the effluent (Table 2).

\section{DISCUSSION}

The significant biomass accumulation over time supported the hypothesis that vetiver grass can be effective on sewage effluent in a floatation system under the local conditions in Harare, tolerating relatively high pollutant levels. However, it was not convincing to attribute the larger fraction of the purification process to plant uptake within the studied 21 days of effluent retention under vetiver grass, as many researchers
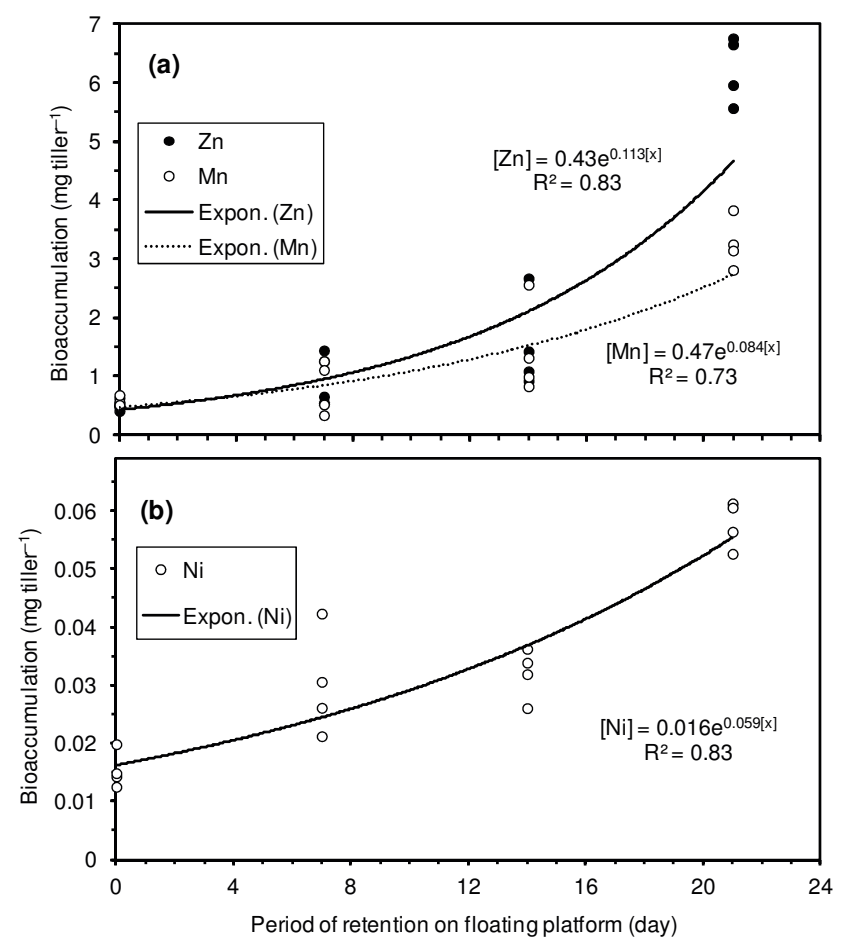

Figure 2

Total extraction of (a) $Z n, M n$, and (b) Ni per tiller of vetiver grass on $9 \ell$ of sewage effluent and its relationships with the period of retention on the floating platform. have demonstrated (e.g. Chomchalow, 2003; Gupta et al., 2012; Aksorn and Chitsomboon, 2013). This was mainly because the reduction in heavy metal amounts in the effluent was considerably higher than the corresponding plant uptake of the heavy metals, especially for Ni. Thus, there could have been other mechanisms responsible for effluent cleaning, which were favoured more in the presence of vetiver grass. One such mechanism could be bio-sorption in which the microorganisms and colloidal sludge particles exhibit metal-binding capacities related to metabolic or physico-chemical processes (Ahalya et al., 2003). This mechanism may also explain why the effluent under no vetiver grass showed some natural self-purification over time, although at a considerably lower rate than the effluent under vetiver grass.

The lack of a simple linear relationship between the reduction in heavy metal concentration in effluent and the retention time suggests multiple heavy metal removal mechanisms. According to Prasad (2011), experimental evidence showing nonlinear kinetics of disappearance of metals from solutions suggests that several different mechanisms, of differing speeds, operate simultaneously. The researcher added that the fastest mechanism is surface absorption by roots, followed by biosorption in which microbial, fungal or other biomass, living or dead, is used to take away large quantities of heavy metals. Microorganisms exhibit a strong ability to accumulate (bioaccumulate) metal and metalloids from substrates containing extremely low concentrations of these elements (Bolan et al., 2010). Over time a film of microorganisms develops on the support surfaces, which Ahalya et al. (2003) referred to as 'adsorption on inert supports'. In this study the support surface could imply the inside walls of effluent containers. Das et al. (2008) referred to it as an 'immobilised microbial biomass' that can be reused in extracting more pollutants in a bioreactor setup. In their study on phytoextraction of $\mathrm{Cu}, \mathrm{Zn}$, and $\mathrm{Pb}$ enhanced by chelators with vetiver grass, Chen et al. (2012) also attributed some discrepancies in their data to metal adherence to the experimental tank. This mechanism could be largely responsible for heavy metal reduction in the effluent. The roots of vetiver grass could have supported microbial life through provision of a habitat in the rhizosphere.

The roots of grasses can produce exudates that can increase the bio-availability of heavy metals, e.g., phytosiderophores that are biosynthesised from nicotinamide (Jabeen et al., 2009), or exudates that precipitate heavy metals from solution (Prasad, 2011). There was no clear evidence of exudation by vetiver grass roots as the effluent $\mathrm{pH}$ was maintained at a stable level above neutral. Phytosidephores are a family of acid-producing chelators produced by roots to solubilise the external insoluble metal nutrients, especially iron (Shojima et al., 1990). Prasad (2011) referred to plant removal of heavy metals from solutions through exudates as the slowest mechanism in comparison with surface absorption and bio-sorption. Under acidic conditions the solubility of most heavy metals is increased, while alkaline conditions generally result in precipitation of heavy metals. A low uptake of heavy metals would therefore be expected from the studied effluent considering that its $\mathrm{pH}$ was above neutral. In some batch experiments by Kumar et al. (2013) it was noted that higher pH (4-8) has no effect on $\mathrm{Cr}$ (VI) removal from effluents by vetiver grass, but that at $\mathrm{pH} 3.5, \mathrm{Cr}(\mathrm{VI})$ removal increased to $55 \%$, and at $\mathrm{pH} 2.5$ metal bio-sorption was maximum around $97 \%$. Thus, it would be necessary to make the local effluent slightly acidic in order to improve the availability of heavy metals for uptake by vetiver grass. 
The results showed an exponential increase in heavy metal extraction by the grass as time progressed, which is encouraging as it reflected the contribution of increased root biomass that could be achieved by increasing the retention time. Zinc had the highest uptake rates and this was consistent with a study by Aksorn and Chitsomboon (2013) that established that all vetiver ecotypes display a high capability for $\mathrm{Zn}$ uptake in both shoots and roots after 7 days of retention. The Aksorn and Chitsomboon (2013) study reported Zn uptake by vetiver grass (Vetiveria zizanioides and $V$. nemoralis) in the range of 8714 to $23285 \mathrm{mg} \cdot \mathrm{kg}^{-1}$, from an aqueous solution containing $500 \mathrm{mg} \mathrm{kg}^{-1}$ of $\mathrm{Zn}$, and concluded that vetiver grass is a good hyperaccumulator only for $\mathrm{Zn}$. However, in many studies the level of uptake depended on the amount of $\mathrm{Zn}$ in the media and the retention time; e.g., Chen et al. (2012) found an average $\mathrm{Zn}$ uptake of $229 \mathrm{mg} \cdot \mathrm{kg}^{-1}$ at Day 7 of retention time, from a solution containing only $5 \mathrm{mg} \cdot \mathrm{kg}^{-1} \mathrm{Zn}$.

There have been relatively few studies on the uptake of $\mathrm{Mn}$ and $\mathrm{Ni}$ by vetiver grass, as the choice of most researchers has largely been on $\mathrm{Zn}, \mathrm{Cd}$ and $\mathrm{Pb}$. In a study by Roongtanakiat et al. (2007), Mn was recorded in higher concentrations (125 $\mathrm{mg} \cdot \mathrm{kg}^{-1}$ in shoot, $188 \mathrm{mg} \cdot \mathrm{kg}^{-1}$ in root $)$ than $\mathrm{Zn}\left(26 \mathrm{mg} \mathrm{kg}^{-1}\right.$ in shoot, $140 \mathrm{mg} \cdot \mathrm{kg}^{-1}$ in root), despite the higher concentrations of Zn $\left(13.8-126.4 \mathrm{mg} \cdot \ell^{-1}\right)$ than $\mathrm{Mn}\left(0.2-8.3 \mathrm{mg} \cdot \ell^{-1}\right)$ in the wastewater. According to Truong (1999), the distribution of heavy metals in vetiver grass can be divided into 3 groups: (i) very little of the $\mathrm{As}, \mathrm{Cd}, \mathrm{Cr}$ and $\mathrm{Hg}$ absorbed was translocated to the shoots (1-5\%); (ii) a moderate proportion of $\mathrm{Cu}, \mathrm{Pb}, \mathrm{Ni}$ and $\mathrm{Se}$ was translocated to shoots (16-33\%); and (iii) $\mathrm{Zn}$ was almost evenly distributed between shoot and root (40\%). In the current study, it was, however, difficult to explain why the uptake of $\mathrm{Ni}$ was more than 10 times lower than that of $\mathrm{Mn}$ and $\mathrm{Zn}$, despite the exponential accumulation with retention time.

The information contained in the study can be implemented in other parts of the world. The City of Johannesburg used floating wetlands to deal with sewage in Bruma Lake, a small artificial lake located northeast of the Johannesburg CBD (Reid, 2014). The efficacy of these wetlands was, however, never tested. There is therefore also a need for proven cost-effective technologies outside of Harare.

\section{CONCLUSION}

This study confirmed that bioremediation of sewage effluent using vetiver grass under hydroponic conditions is a feasible complementary treatment method that can reduce the amounts of total dissolved solids, $\mathrm{N}, \mathrm{Zn}$ and Mn within 21 days to levels that are acceptable for direct discharge into streams according to the wastewater discharge standards in Zimbabwe. In addition to plant uptake via the roots, other heavy metal removal mechanisms, particularly bio-sorption by microorganisms forming an immobilised microbial biomass on supporting surfaces, would be required to account for the effluent clean-up within 21 days of effluent retention under vetiver grass. There was no evidence to support heavy metal precipitation through root exudates as a mechanism of heavy metal removal since vetiver grass treatment maintained a stable effluent $\mathrm{pH}$ within a very narrow range above neutral. In future, a deliberate lowering of effluent $\mathrm{pH}$ might increase root uptake thereby lowering the effluent residence time under vetiver grass. A longer study covering the changes in redox states and speciation of nutrients and heavy metals in wastewater under vetiver grass treatment is recommended to improve understanding of the absolute contribution of bio-sorption to wastewater treatment.

\section{ACKNOWLEDGEMENTS}

This study received logistical support from the Director of Harare Water, Harare City Council, through Engineer ST Muserere; material support from Environment Africa, a regional non-governmental organisation, through $\mathrm{Mr}$. B. Mawire; and transport and financial support through Mr DM Mudhiriza, for which the authors are extremely grateful.

\section{REFERENCES}

AHALYA N, RAMACHANDRA TV and KANAMADI RD (2003) Biosorption of heavy metals. Res. J. Chem. Environ. 7 20-30.

AKSORN E and CHITSOMBOON B (2013) Bioaccumulation of heavy metal uptake by two different vetiver grass (Vetiveria zizanioides and Vetiveria nemoralis) species. Afr. J. Agric. Res. 8 3166-3171.

APHA (1999) Standard Methods for the Examination of Water and Wastewater $\left(20^{\text {th }}\right.$ edn). American Public Health Association, Washington DC.

BOLAN N, NAIDU R, CHOPPALA G, PARK J, MORA ML, BUDIANTA D and PANNEERSELVAM P (2010) Solute interactions in soils in relation to the bioavailability and environmental remediation of heavy metals and metalloids. Pedologist 53 1-18.

BOONSONG K and CHANSIRI M (2008) Domestic wastewater treatment using vetiver grass cultivated with floating platform technique. Assumption Univ. J. Technol. 12 73-80.

CAMPBELL RC and PLANK CO (1998) Preparation of plant tissue for laboratory analysis. In: Kalra YP (ed.) Handbook of Reference Methods for Plant Analysis. Soil and Plant Analysis Council, Inc. CRC Press, Taylor \& Francis Group, New York.

CHEN KF, YEH TY and LIN CF (2012) Phytoextraction of Cu, $\mathrm{Zn}$, and $\mathrm{Pb}$ enhanced by chelators with vetiver (Vetiveria zizanioides): Hydroponic and pot experiments. Ecology DOI:10.5402/2012/729693.

CHOMCHALOW N (2003) The role of vetiver in controlling water quantity and treating water quality: An overview with special reference to Thailand. Assumption Univ. J. Technol. 6 145-161.

CMEC (2013) Development and rehabilitation of municipal water and sewage treatment works for Zimbabwe. China Machinery Engineering Corporation (CMEC), Hong Kong. URL: http:// www.hkexnews.hk/listedco/listconews/sehk/2013/0628/ LTN20130628955.pdf (Accessed 10 July 2013).

DAS N, VIMALA R and KARTHIKA P (2008) Biosorption of heavy metals - an overview. Ind. J. Biotechnol. 7 159-169.

ENVIRONMENTAL MANAGEMENT (EFFLUENT and SOLID WASTE DISPOSAL) REGULATIONS (2007) Statutory Instrument of 2007. [CAP.] Office of the Attoney-General, Harare.

GERRARD MA (2008) The ability of vetiver grass to act as a primary purifier of waste water; an answer to low cost sanitation and fresh water pollution. The Vetiver Network International, Texas. URL: http://www.vetiver.org/SA_phytoremediation.pdf (Accessed 10 July 2013).

GUPTA P, ROY S and MAHINDRAKAR AB (2012) Treatment of water using water hyacinth, water lettuce and vetiver grass - A review. Resour. Environ. 2 202-215.

GUTTERER B, SASSE L, PANZERBIETER T and RECKERZUGEL T (2009) Decentralised Wastewater Treatment Systems (DEWATS) and Sanitation in Developing Countries: A Practical Guide. Loughborough University of Technology, Loughborough.

JABEEN R, AHMAD A and IQBAL M (2009) Phytoremediation of heavy metals: physiological and molecular mechanisms. Bot. Rev. 75 339-364.

KUMAR M, PAL A, SINGH J, GARG S, BALA M, VYAS A, KHASA YP and PACHOURI UC (2013) Removal of chromium from water effluent by adsorption onto Vetiveria zizanioides and Anabaena species. Natural Sci. 5 341-348.

MADYIWA S, CHIMBARI M, NYAMANGARA J and BANGIRA C (2002) Cumulative effects of mixture application on soil properties of a sandy soil under a mixture of Star and Kikuyu grass in Zimbabwe. Phys. Chem. Earth 27 747-753. 
MAFFEI M (2002) Introduction to the genus Vetiveria. In: Maffei M (ed.) Vetiveria: The genus Vetiveria. Taylor and Francis, London.

MAHAMADI C (2011) Water hyacinth as a biosorbent: A review. Afr. J. Environ. Sci. Technol. 5 1137-1145.

MAPANDA F, MANGWAYANA EN, NYAMANGARA J and GILLER KE (2005) The effect of long term irrigation using wastewater on heavy metal contents of soils under vegetables in Harare, Zimbabwe. Agric. Ecosyst. Environ. 107 151-165.

MAPANDA F, MANGWAYANA EN, NYAMANGARA J and GILLER KE (2007) Uptake of heavy metals by vegetables irrigated using wastewater and the subsequent risks in Harare. Phys. Chem. Earth 32 1399-1405.

NDEBELE M and MZIME R (2012) Biological monitoring and pollution assessment of Mukuvisi river, Harare, Zimbabwe. Lakes Reservoirs Res. Manag. 17 73-80.

NHAPI I (2009) The water situation in Harare, Zimbabwe: A policy and management problem. J. Water Polic. 11 211-235.

NYAMANGARA J and MUZEZEWA J (1999) The effect of long-term sewage sludge application on $\mathrm{Zn}, \mathrm{Cu}, \mathrm{Ni}$ and $\mathrm{Pb}$ levels in a clay loam soil under pasture grass in Zimbabwe. Agric. Ecosyst. Environ. 73 199-204.

PAZ-ALBERTO AM and SIGUA GC (2013) Phytoremediation: A green technology to remove environmental pollutants. Am. J. Clim. Change 2 71-86.

PESCOD MB (1992) Wastewater treatment and use in agriculture. FAO Irrigation and Drainage Paper No. 47. Food and Agriculture Organization of the United Nations, Rome. 125 pp.

PRASAD MNV (2011) A state-of-the-art report on bioremediation, its applications to contaminated sites in India. Ministry of Environment and Forests, New Delhi. URL: http://moef.nic.in/ downloads/public-information/BioremediationBook.pdf (Accessed 9 January 2014).

REID LJ (『2014) The Bruma Lake clean-up operation. Civ. Eng. 22 80-81. ROONGTANAKIAT N (2009) Vetiver phytoremediation for heavy metal decontamination. Technical Bulletin No. 2009/1. Pacific Rim Vetiver Network, Texas. URL: http://www.vetiver.org/THA_ Vetiver\%20Phytoremediation_o.pdf (Accessed 10 July 2013).
ROONGTANAKIAT N, TANGRUANGKIAT S and MEESAT R (2007) Utilization of vetiver grass (Vetiveria zizanioides) for removal of heavy metals from industrial wastewaters. Sci. Asia 33 397-403.

SAUTER A and STOUB K (1990) Waters and salt. In: Helrich K (ed.) AOAC Official Methods of Analysis ( $\left.15^{\text {th }} \mathrm{edn}\right)$. Association of Official Analytical Chemists (AOAC), Inc. Arlington, Virginia.

SHOJIMA S, NISHIZAWA NK, FUSHIYA S, NOZOE S, IRIFUNE T and MORI S (1990) Biosynthesis of phytosiderophores. Plant Physiol. 93 1497-1503.

THEBE TA and MANGORE EN (2012) Wastewater production, treatment, and use in Zimbabwe. The UN-Water Activity Information System (UNW-AIS). URL: http://www.ais.unwater.org/ais/ pluginfile.php/231/mod_page/content/178/zimbabwe_country_repor_\%20for_capacity_development_project_on_was_2.pdf (Accessed 11 July 2013).

TRUONG P (1999) Vetiver grass technology for mine rehabilitation. PRVN Technical Bulletin No. 1999/2. Office of the Royal Development Projects Board, Bangkok, Thailand. URL: http:// www.vetiver.com/PRVN_mine-rehab_bul.pdf (Accessed 4 January 2014).

TRUONG P (2007) Vetiver grass - unique roots. The Vetiver Network, Bangkok. URL: http://vetivernetinternational.blogspot. com/2007/04/vetiver-grass-grass-unique.html (Accessed 3 January 2014).

TRUONG PN and BAKER D (1998) Vetiver grass system for environmental protection. Bulletin No. 1998/1. Pacific Rim Vetiver Network. Office of the Royal Development Projects Board, Bangkok. URL: http://grassland.agron.ntu.edu.tw/VGT_CD_3/ data/FRAME.HTM (Accessed 19 August 2014).

TRUONG PN and HART B (2001) Vetiver system for wastewater treatment. Technical Bulletin No. 2001/2. Pacific Rim Vetiver Network. Office of the Royal Development Projects Board, Bangkok. URL: http://www.vetiver.org/PRVN_wastewater_bul.pdf (Accessed 11 July 2013). 